\title{
MÁLOVICS Éva
}

\section{SZERVEZETI KULTÚRA ÉS VEZETÉS - LEHETŐSÉGEK ÉS KORLÁTOK}

A szervezeti kultúra egy olyan jelenségkör, amelyról sok szó esik a szakirodalomban, azonban tartalmáról és jellemzóiról nem alakult ki olyan konszenzus, aminek alapján létrejött volna egy elfogadott meghatározás, az empirikus vizsgálatok is ellentmondásosak. A tanulmány központi kérdése: mit mond a kulturális megközelítés a vállalatvezetốknek? A szerzố dolgozatában 4 vállalatnál készített, lazán strukturált interjúk tartalomelemzésének eredményeit közli. Célja e tanulmány keretei között az, hogy a gyakorló szakemberek figyelmét felhívja a kultúra olyan aspektusaira, amelyek az elméletekból kiolvashatók, és amelyekkel az empirikus vizsgálataiban szereplő vállalatok gyakorlatának tipikus problémái jól értelmezhetók, s hogy e tudás hasznosításával e „menedzsmentdilemmákra” vélhetôen jobb megoldások legyenek találhatók.

Kulcsszavak: szervezeti kultúra, vezetés, szervezeti magatartás

A szervezeti kultúra egy olyan jelenségkör, amelyról sok szó esik a szakirodalomban, azonban tartalmáról és jellemzóiról nem alakult ki olyan konszenzus, aminek alapján létrejött volna egy elfogadott meghatározás, az empirikus vizsgálatok is ellentmondásosak. Ennek egyik kézenfekvő oka az, hogy maga a kultúrafogalom sem egységes. A szervezeti kultúra fogalma az 1970-es évektól vált sikerfogalommá, a nyolcvanas évek elejére sokan komoly kutatási témának tartották. A vállalati kultúra kutatások mellett a nemzeti kultúrák vizsgálata, ezek eltérései és a különbségek hatása a szervezetekre szintén jelenốs témakörré vált, ezt a gazdaság globalizációjának felgyorsulása miatt ma is sokan aktuálisnak tartják (Bakacsi - Takács, 1998; Bakacsi - Sarkadi-Nagy, 2003.).

A szervezeti kultúra szerepének és jelentőségének legnépszerúbb taglalása Peters és Waterman „A siker nyomában" címú sokat vitatott múvében található. A szerző́k néhány „,kiváló” amerikai vállalatnál gyuujtött esetpéldával próbálják bizonyítani, hogy a szervezet filozófiájának, kultúrájának, a tagok által közösen vallott értékeknek nagyobb szerepe van a szervezet sikerességében, mint más múszaki és gazdasági jellemzóinek, ezzel az emberi eróforrásban rejló értékekre hívják fel a figyelmet (Peters - Waterman, 1986).

A szervezeti kultúra témaköre nyilvánvalóan a vezetés emberközpontú szemléletéhez tartozik, sokan úgy látják, hogy a szervezeti kultúra fogalom felhasználásával, a nyolcvanas évek elejétól, a gyorsan változó, komplex környezet kezelésének problémájára próbálnak egyfajta választ adni. Ezzel kapcsolatban több szerzó paradigmaváltást emleget. „A paradigmák változásának kényszerítő erejú okozója a tágan és komplexen értelmezett környezet" (Farkasné, 1990: p. 25.). A sok ellentmondás, a túl sok információ és a nagyfokú bizonytalanság sokak szerint a vezetés kollektivizálódásával, a participáció fokozódásával kezelhetốbbé válik. Hasonló módon támasztják alá a kultúra jelentôségét a tudásalapú vállalatelméletek és a humán eróforrásokkal kapcsolatos elméletek.

A nyolcvanas évek végére az alkalmazásorientált, a funkcionális vezetési megközelítések szerepe is egyre jelentősebb. E megközelítés hívei a szervezeti kultúrát a vezetés egyik alrendszerének tekintik, a vezetói kontroll egyik eszközeként értelmezik, amely hozzájárulhat a szervezetekben a pszichológiai szerzôdés normatív formájának kialakulásához és fenntartásához. Ez a vezetést tekintve azzal a következménnyel jár, hogy foglalkoznia kell azzal, hogy a dolgozók mit gondolnak és miben hisznek, eszerint a vezetés egy értékalakító folyamatot is magában foglal. A szakirodalomban erős hangsúlyeltolódás tapasztalható a puha tényezók, a vezetési stílus és a közös értékek felé. 
Nagy számban születtek olyan témájú írások is, amelyek a kultúra és a sikeresség kapcsolatát elemzik, és gyakorlati útmutatót, tanácsokat, ,recepteket” adnak a kultúra olyan irányú változtatásához, alakításához, amely a szervezeti eredmény növeléséhez hozzájárul.

A gyakorlati alkalmazás tehát megkezdődik, mielőtt a tudomány a legalapvetốbb területeken egyetértene. Az utóbbi évtizedekben rohamosan növekvő szervezeti kultúra irodalom még sok kérdés megválaszolásával adós maradt, tudományos körökben sok vonatkozása még vitatott, a kultúra továbbra is érdekes kutatási terület, az alapkérdésekben is még csak sokára várható konszenzus, amennyiben ez egyáltalán lehetséges. E sokszínúségnek és ellentmondásosságnak alighanem a kultúrafogalom komplexitása („hagymaszerú jellege") az oka, a kutatók kénytelenek voltak különbözó leegyszerúsítéseket végezni azért, hogy definiálhassák és kutathassák, ezt természetesen mindenki a saját szemszögéból, az általa fontosnak tartott szempontok előtérbe helyezésével tette. Edgar Schein a következőképpen fogalmazta meg a szervezeti kultúra fogalma körüli ellentmondásokat: „A szervezeti kultúra koncepciója létrejött, de még nem világos, hogy miként válik a szervezettel kapcsolatos tudományok használható és életképes elemévé. Ahogy én látom, a probléma a magdefiníció körül van mind a formális, konceptuális nézôpontból, mind a gyakorlati, alkalmazott nézőpontból. Nem tudunk létrehozni egy használható koncepciót, ha nem tudunk megegyezni abban, hogy hogyan definiáljuk, „mérjük, vizsgáljuk, és alkalmazzuk azt a szervezetek valódi világában.” (Schein, 1991: p. 243.)

További jelentôs különbség tapasztalható a tudományos megközelítések és a szervezetek gyakorlati múködéséhez tanácsot adó tevékenységek és írások között, amelyek gyakran a szervezeti kultúra igen leegyszerúsített modelljével dolgoznak.

Tanulmányunk célja természetesen nem az, hogy rendet teremtsünk a kultúrafogalmak, operacionalizálások és vizsgálatok dzsungelében. Célunk e tanulmány keretei között az, hogy a gyakorló szakemberek figyelmét felhívjuk a kultúra olyan aspektusaira, amelyek az elméletekból kiolvashatók, és amelyekkel az empirikus vizsgálatainkban szereplố vállalatok gyakorlatának tipikus problémái jól értelmezhetók, s hogy e tudás hasznosításával e „menedzsment-dilemmákra” vélhetően jobb megoldások legyenek találhatók.

\section{A szervezeti kultúra definíciói}

A szervezetkutatók a kultúra fogalmát az antropológiából vették át, s ugyanúgy nem sikerült konszenzust kialakítaniuk a fogalom tartalmáról és konceptualizálásáról. A több százra tehető kultúrafogalom közül csak néhány, témánk szempontjából jelentôsebbet emelünk ki:

- Deal és Kennedy (1982): „Az erốs kultúra informális szabályok rendszere, amely világossá teszi, hogy az emberek hogyan viselkedjenek az esetek többségében." (p. 32.)

- Cooke - Rousseu (1988): „A közös hitek és értékek, amelyek az emberek gondolkodását és viselkedésmódját vezérlik." (p. 24.)

- Smircich (1983): „Szociális és normatív kötőanyag, ami összetartja a szervezetet... az értékek vagy szociális ideálok és hitek, amiket a szervezeti tagok közösen elfogadnak. Ezek az értékek vagy hiedelem minták olyan szimbólumokban öltenek testet, mint a mítoszok, rituálék, sztorik, legendák és a speciális nyelvezet." (p. 344)

- E. H. Schein: „Közös alapfeltevések mintázata,

1. amelyet egy adott csoport fedezett fel, illetve fejlesztett ki,

2. miközben megtanult megbirkózni a külső alkalmazkodás és a belső integráció problémáival,

3. s amely alapfeltevések elég jól múködnek ahhoz, hogy érvényesnek tekintsék ôket,

4. s a csoport új tagjainak átadják ôket,

5. mint a problémák észlelésének, a róluk való gondolkodásnak és a velük kapcsolatos érzéseknek a helyes módját." (Schein, 1991: p. 247.)

- Geert Hofstede: „,...a gondolkodás közösségi programozottsága, amely megkülönbözteti az adott csoporthoz tartozó embereket egymástól. ...a kultúra magában foglalja az értékrendszereket, így az értékek a kultúra építókövei. A kultúra az emberi közösségek számára azt jelenti, mint az egyének számára az egyéniség... azaz az önmagával való azonosságot határozza meg. (Hofstede, 1980: p. 25.)

Meyerson és Martin kultúramegközelítés csoportosítása szerint a szakirodalomban három nagyobb megközelítés dominanciája figyelhetô meg: Az integrációs, a differenciációs és a fragmentációs megközelítés (részletesen lásd: Málovics - Behrends, 2002), a menedzsment tudományok általában az integrációs megközelítés szempontjából foglalkoznak a kultúra kérdéskörével, amely a szervezeti kultúrának a következő lényeges hatásokat tulajdonítja:

- a kultúra közös voltát, átörökítését a szocializáción keresztül,

- a kultúra implicit jellegét, s emiatt a vizsgálhatóság nehézségeit,

- a kultúra jelentéstulajdonító szerepét; amely szoros kapcsolatban áll az elkötelezettséggel és a szervezeti integrációval, 
- a különböző helyzetek közös értelmezését bizonyos irányelvek kialakulásakor a viselkedést illetôen,

- előfordul, hogy annyira meghatározónak tartják a kultúrát, hogy a struktúrát és a stratégiát is ebból származtatják,

- Schein a kultúrának a csoportot stabilizáló, integráló funkciót tulajdonít, amely jelentéssel ruházza fel a környezetet, és támpontokat nyújt a válaszokhoz,

- Hofstede a szervezeti kultúra vonatkozásában a nemzeti kultúrák hatását emeli ki, amely szerinte nagymértékben irányítja az egyéni és a társas viselkedést, s ezen keresztül a szervezetek kultúráját.

\section{Milyen szerepet tölt be a leírtak tükrében a kultúra a szervezetek vezetésében?}

A szervezettel és a vezetéssel kapcsolatos elméletek terén két egymás mellett élő megközelítés figyelhetố meg. A dologi technikai irányzatok szerint a szervezetek vezetése fóként mechanisztikus probléma. A szervezetet úgy kell megtervezni, hogy az önérdeküket követô alkalmazottakat az ösztönzők és a szankciók a szervezeti célok megvalósítása irányába tereljék. A vállalat dolgozói magatartásának irányítása, formálása tehát fớként jutalmak és büntetések rendszerén keresztül lehetséges, ehhez a menedzsment kontrollját, amennyire lehetséges, ki kell terjeszteni. A mechanisztikus szemlélet újabb verziója a közgazdaságtan „megbízó-megbízott" elmélete, amely szerint a megbízottak világos preferenciákkal rendelkeznek, és haszonmaximáló egyénekként követik céljaikat. A megbízó feladata ebból következóen a megbízottak racionális reakcióinak előrejelzése és a megfelelő ösztönzőrendszer kidolgozása, amely a megbízottakat érdekeltté teszi abban, hogy a legjobban végezzék tevékenységüket. A vezetés feladata eszerint a szervezet gépezetének megtervezése, ha megfelelő az ösztönzőrendszer, nincs szükség egyéb motivációra. Ettől meglehetôsen különbözik a szervezetek és a vezetés másik, organikusabb megközelítése, amely a szervezetpszichológiából és a szociológiából meríti elméleti alapjait. E megközelítésben a vezetés lényege a beosztottak inspirálása, együttmúködésük megszerzése. Eszerint a vezetés alapvetó kérdései az emberi kapcsolatokhoz füződnek, mivel ezek az emberi teljesítményt meghatározó tényezőnek tekinthetôk. A vezetés egyik központi tevékenységének az emberi alkotómechanizmus támogatását tartják, hiszen a szervezeti eredmények nagymértékben ettól függnek. „A különbség a két szemlélet között világos. A közgazdászok feltételezik, hogy a beosztottak az ösztönzőrendszerekre önérdeküket szem előtt tartva, saját hasznukat maximalizálva reagálnak. Barnard ezzel szemben azt javasolja a menedzsereknek, hogy „erkölcsi” példamutatással ösztönözzék ,áldozathozatalra" beosztottjaikat. A közgazdászok Barnard törekvéseit hiábavalónak tekintik; a politikatudomány múvelói és a behavioristák viszont úgy érzik, hogy a szervezeti gazdaságtan a vezetés lehetséges aspektusainak csupán egy borzasztóan szúk szeletéról vesz tudomást, és politikailag naiv." (Miller, 2002: p. 13.)

A vezetéssel foglalkozó tudományok egyik központi kérdése tehát az emberi viselkedés befolyásolása és szabályozása, aminek megoldatlansága miatt a szervezetek múködését és múködtetését nagyfokú bizonytalanság jellemzi. A másik nagy horderejú kérdés az emberi tevékenység korlátok közé szorításával kapcsolatban, hogy meddig célszerú e korlátokat szúkíteni? A különbözố irányzatú szerzôk erre más-más választ adtak. Napjaink gyorsan változó környezetéhez történő alkalmazkodás úgy túnik az egyéni viselkedés nagy szabadságfokát igényli. A szervezeti sikeresség szempontjából következik az újabb kérdés, hogy a szervezeti tagok hogyan élnek ezzel a szabadsággal, milyen szempontok szerint használják ki azt, azaz mennyire és milyen értelemben motiváltak?

C. Barnard (1938) klasszikus múvében amellett érvelt, hogy a szervezetek lényegét az egyének együttmúködő csoportjai alkotják, és a vezetô legfontosabb feladata az együttmúkoodés elômozdítása, az ,áldozathozatalra" való lelkesítés, és nem az önérdekkel történő manipulálás. A magatartástudományok azóta is állítják a kooperáció és az elkötelezôdés normáinak jelentôségét a szervezetben, ami nyilvánvalóan szemben áll a neoklasszikus közgazdaságtan nézeteivel. G. J. Miller a játékelmélet hozzájárulására hívja fel a figyelmet, az ismételt játékok elemzéséból született vizsgálatokra, amelyek a kooperáció lehetőségeit tárják fel, s amelyek felfedezéseinek tükrében ,a szervezeti közgazdaságtan és a szervezeti viselkedés közti éles különbség elhalványul. A közgazdasági értelemben véve racionális gazdasági menedzsert a személyközi kommunikáció, bizalom és lojalitás ugyanazon témái foglalkoztatják, mint amelyek a szervezeti viselkedés tanulmányozóinak központi érdeklődési körébe tartoznak." (Miller, 2002)

A vezetés egyik legfontosabb kérdése tehát, hogyan befolyásolható az ember ebben a sávban. A kérdés megválaszolásában az integrációs irányzat szerint a kultúrának mint a szervezeti tanulás, a szocializáció és a rutinok alakítójának és hordozójának, napjainkban központi szerep jut.

G. J. Miller Menedzser-dilemmák címú múvében a „szervezeti gazdaságtan és a szervezeti viselkedés tudománya között próbál meg hidat verni”, s a hierar- 
chiák vizsgálata során arra a következtetésre jut, „,hogy azok a szervezetek, amelyeknek a vezetői képesek beosztottjaikat rövid távú önérdekük meghaladására ösztönözni, minden esetben versenyelőnyre tesznek szert. A játékelméleti kísérletek tükrében, úgy véli, „új és eleven jelentést nyernek az olyan hagyományos organikus fogalmak, mint az együttmúködés, a kultúra, a bizalom, az elkötelezettség vagy a személyes vezetés (Miller, 2002: p. 14.).

A magatartástudományi alapú megközelítések a szervezeti kultúrát, mint a vezetés eszközét a szervezeti hatékonyság következő tényezőivel hozzák a leggyakrabban összefüggésbe:

- A vállalati kiválóság, sikeresség hátterében a szervezeti kultúra áll. Sok szerző vállalati esetpéldák tömegével próbálja bizonyítani (Peters, Waterman, Salamon stb.), hogy a siker elengedhetetlen feltétele a „,közös értékrendszer”, vagy a fölérendelt célok, amikben az emberek hisznek, és amiket húségesen szolgálnak.

- A szervezeti kultúra a motiváció növelésének forrása. A szervezeti kultúrával kapcsolatos múvekben gyakran bukkan fel a feltételezés, hogy a megfeleló kultúra a tagok jobb motiváltságát eredményezi, ami versenyelőnyhöz juttathatja a szervezetet. A motivációval kapcsolatos kutatások eredményeiból tudjuk, hogy az extrinzik és intrinzik motiváció ,nem öszszegződő tényező". A jutalom bizonyos esetekben csökkentheti az érdeklődést, ha a jutalom kontrolláló hatással jár együtt, ez csökkenti a belső motivációt, ha azonban a jutalom információs oldala hangsúlyos, azaz megerôsíti a személyt kompetenciájában és öndeterminációjában, akkor a belsố motiváció fennmarad (Deci, 1981 in: Kim, 2000). Mindez alátámasztja a vezetés kulturális tényezőinek jelentőségét a belső motiváció kialakításában és fenntartásában.

- A megfelelóen kialakított szervezeti kultúra a koordináció magasabb fokát hozza létre: „Jól múködő vállalati kultúra esetén nincs szükség minden lépést részletesen leíró tervekre, eljárásokra és programokra, hiszen a szervezet szereplőinek értékei, hitei és viselkedési mintái bizonyos szinten ellátják a koordináló és irányító szerepet." (Bencze, 1997: 18. o.) „A gondolatmenet egyszerú: ha a vállalat dolgozói elfogadnak, és egyöntetúen érvényesítenek bizonyos alapvetó vállalati értékeket, akkor a vállalat teljesítménye javulni fog, mivel az alkalmazotti gárda ,egy irányba húz" - állandó és közvetlen vezetői beavatkozás nélkül is.” (Bôgel-Salamonné, 1998: 94. o.)

- A kultúra a vezetôi kontroll korszerú eszköze. A William Ouchi által kidolgozott tipológiában már megjelenik a piaci és bürokratikus kontroll mellett a klán kontroll, amely abban különbözik az előzô kettôtől, hogy nem valamiféle külsô normán vagy szabályon alapul. A klánkontroll a kulturális normák által történt szocializáción alapul, és informális mechanizmusokon keresztül hat, ezért az várható tôle, hogy a szervezeti tagok közötti érdekellentét csökken, mivel fontos eleme a normákkal, szabályokkal való azonosulás.

- A kultúra a szervezeti tudás egyik jelentôs területe, illetve hordozója: Varga Károly az „új múszaki kultúra" megjelenésének következményeit elemezve fontosnak tartja az ennek megfelelő új struktúrát, amely a vezetői szintek csökkenését jelenti a szervezetben. „Közismert, hogy a japán sikerek egyik leleplezett titka: a Toyotánál négyszer kevesebb vezetői szint volt, mint a Fordnál a nagy ,irtás" előtt." (Varga, 1992: p. 2.) A másik ebból következő jelenség a szakértő, aki a legjobban ért az adott dologhoz a szervezetben, ezért nem dönthet helyette semmilyen „felettes”. „A tudás alapvetően az egyének sajátja, de a szervezeten belül is tudás jön létre. ...a vállalat tudása tehát azokba a szervezốelvekbe van beágyazódva, amelyek alapján az emberek a szervezeten belül kooperálnak, azaz a vállalat tudása társadalmi jellegú." (Kapás, 1999: p. 9. o.)

- A kultúra a szervezeti változások hordozója, illetve lassító, akadályozó tényezóje, azaz lényeges eleme. A szervezetfejlesztés értelmében vett lassú változás koncepciójában a kulturális tényezók központi szerepet játszanak. Szervezetfejlesztésen ,,a szociális rendszerek változási folyamataihoz szükséges részletes tervezési, kezdeményezési és megvalósítási koncepciót értik" (Thom, 1999: p. 5.). Az SZF következményei: a munkakörülmények demokratizálása, a hatalmi viszonyok kiegyenlítettebbé válása, a kölcsönös bizalom kialakulása. Kinyilvánított célja az, hogy a tagok meg tudjanak birkózni a változásokkal, és támogassák azokat. E koncepció központi gondolata a szervezeti érték- és tudásbázis megváltoztatása, ezáltal a probléma megoldási és cselekvési kompetenciák javítása és az egyén tudásának kollektivizálása, e folyamat intézményesítése és támogatása.

E gondolatok mentén alakult ki a tanuló kultúra és tanuló szervezet modellje (Schein,1991; Kocsis-Szabó, 2000 stb.), amelyet sokan napjaink gyorsan változó környezetében a sikeres alkalmazkodás feltételének tekintenek. Egyre többen hívják fel a figyelmet a virtuális szervezetek organikus jellegzetességeire, ezt szembeállítva a bürokratikus szervezetek mechanikus jellegú kultúrájával (Drótos, 2005). Úgy véljük, témánk szem- 
pontjából e megkülönböztetés alapvetô jelentôségú. A legtöbb modell, amely típusokba sorolja a szervezeti kultúrákat, implicit vagy explicit módon magában foglalja a mechanikus, illetve organikus kultúra típusokat, s ezek valamilyen arányú keverékébő́l állít elố különböző kultúratípusokat.

Burns és Stalker (1961) a környezethez rugalmasan alkalmazkodni képes kevesebb hierarchiai szinttel jellemezhetố szervezeteket organikus szervezeteknek nevezi, és megkülönbözteti a mechanikus szervezetektól, amelyeket nagyobb mélységi tagoltsággal és jobban specializált munkakörökkel jellemezhetô struktúrákként ír le. E megkülönböztetés a vállalatvezetók szervezetszemléletében is megjelenik. Ha a szervezetet gépként fogjuk fel, akkor a folyamatokat ennek megfelelően mechanikus szemlélettel szervezzük, az emberi tényezôt háttérbe szorítjuk. „Ha az emberek organikusan értelmezik a szervezetet, akkor abban inkább egy szociális, társadalmi képződményt látnak, amely a szervezet tagjainak szükségletei és lehetôségei szerint fejlődik.” (Borgulya - Barakonyi, 2004: p. 143.)

Slevin és Kovin a mechanikus és az organikus kultúrákat a következó dimenziók mentén különböztetik meg egymástól.

Az organikus kultúra jellemzői:

- kommunikációs csatornák nyitottsága,

- szabad információáramlás,

- egyéni szaktudásra épülő múködési stílus,

- önkéntes alkalmazkodás a változó körülményekhez,

- hangsúly az ügyek elvégzésén, szabályozás nélkül,

- laza ellenốrzés,

- rugalmas munkahelyi magatartás,

- csoportos döntéshozatal.

A mechanikus kultúra jellemzői:

- ellenőrzött információáramlás,

- múködési stílus előírt,

- hierarchikus döntési jogosultság,

- lassú alkalmazkodás,

- hangsúly az írott, bevált szabályokon,

- ellenôrzési rendszerekkel kontroll,

- munkahelyi, munkaköri magatartási előírások,

- vezetốk döntenek véleménykérés nélkül.

A mechanikus kultúra állandó környezetben és monopolhelyzetben megfelelô, az organikus kultúra változó környezetben is jól múködik (Heidrich, 2001).

A szervezetfejlesztés törekvései a szervezeti tagok és csoportok változtatása terén a szervezeti kultúrának organikus irányba történó változtatása, teszi mindezt a magatartástudományok eredményei alapján. E törekvést a játékelmélet nyelvére lefordítva: a szervezetek világában a szervezetfejlesztés a kooperatív játék lehetôségeire hívja fel a figyelmet, és az ehhez szükséges készségek fejlesztéséhez kínál képzéseket. Ez azért nehéz feladat, mert „feszültség van a nyereségorientált vállalati vezetốk önérdeke és a vállalatok általános, hosszú távú hatékonysága között. Megoldást az jelenthet, ha a vezetô hitelesen elkötelezi magát a hoszszú távú, kooperatív, hatékony viselkedés mellett. Az elköteleződési problémára kínálkozó megoldások az ösztönzőrendszerek és a hierarchia mechanikus világából a vezetés és a politikai hatalom organikus világába vezetnek át.” (Miller, 2002: p. 342. o.)

\section{Az empirikus kutatások eredményei}

$\mathrm{Az}$ empirikus kutatásaink alapját Mastenbroek szervezetfejlesztési célú megközelítése képezi, aki a szervezeti kultúra lényegének a magatartásformák tendenciáit („Milyen viselkedésmintákat mutatnak a csoportok? Milyen vezetési stílus a domináns? Hogyan kezelik a kölcsönös kapcsolatokat a döntéshozatal és a problémamegoldás során?") és a szervezet dinamikáját (,Milyen feszültségek és problémák léteznek az egyes egységek között? Milyen sztereotip viselkedésformák és elképzelések dominánsak? Milyen légkör uralkodik a szervezeteken belül? Melyek a visszatérô problémák?) tartja. Ezek a vállalati gyakorlat számára fontos kérdések, olyan előre nem tervezett következményekre és visszatérố nem hatékony magatartásokra utalnak, amelyekbe a csoportok könnyen belegabalyodnak.

Empirikus vizsgálatainkat lazán strukturált interjúk felvételével készítettük. E tanulmány keretei között négy vállalatnál készített interjúk révén kapott eredményeinket szeretnénk bemutatni. Az interjúk egy rövid vezérfonal mentén készültek, a beszélgetések alatt tág teret biztosítottunk a megkérdezetteknek a téma kifejtésére.

Fốbb témaköreink:

- alapvetố szervezeti értékek megléte, ezek kommunikálása, megjelenése a stratégiában,

- a vezetési stílus,

- munkahelyi légkör,

- kommunikáció, konfliktusok, együttmúködés.

\section{A vizsgált vállalatok}

A megkérdezést szegedi szervezetekben, felsô-, közép-, alsószintú vezető́k és nem vezetốk körében végeztük. Mintánk egy kisvállalatból, valamint két dinamikusan fejlődő, Magyarországon piacvezetőnek tekinthetô, magyar, magántulajdonban lévő - közép- 
vállalatból, amelyek fóként kereskedelemmel foglalkoznak, és egy állami nagyvállalat egyik részlegéból állt. A négy szervezetben összesen 35 emberrel készítettünk interjút.

1. vállalat

Egy kicsi, 25 fốs, de dinamikusan fejlődô számítástechnikával foglalkozó szervezet. A vállalkozás fennállása óta töretlenül növekszik, átlagosan évi 10-20\%-os forgalomnövekedés jellemzi. A vállalkozást alapítása után egy évvel, 20 fốvel és software tevékenységgel bővítették, ami hibás lépésnek minősült. Ez az új tevékenység igen veszteséges volt, így az új tagokat el kellett bocsátani. Ez volt a vállalat egyetlen „nagy válsága”.

2. vállalat

A 2. szervezet, az utóbbi nyolc évben 50 főról 120 főre növekedett, dinamikusan fejlődő szervezet, amely profilját is jelentősen bővítette. A kezdetekkor a szervezet múködését alapvetốn meghatározta az ügyvezetố személye, aki nagy tulajdonhányaddal rendelkezik, és a céget is ô alapította.

3. vállalat

A 3. vállalat egy magyar magántulajdonban lévő középméretú szervezet, amely az elmúlt 12 év során kis szervezetból nagyon dinamikusan fejlődött a jelenlegi szintre, napjainkra a régió papírkereskedelmében meghatározó szerepet játszik. Országos viszonylatban is jelentôsnek tartják.

4. vállalat

Nagy, budapesti székhelyú, az egész országot behálózó, 100\%-os állami tulajdonban lévô szolgáltató részvénytársaság, amelynél szintén a szegedi igazgatóság néhány osztályán végeztük a megkérdezést. Hierarchikus felépítésú, a budapesti vezérigazgatóság alatt több igazgatóság helyezkedik el.

\section{A tartalomelemzés eredményei}

\section{Értékek, stratégia}

A vizsgált kkv-k stratégiájával, kultúrájával kapcsolatos írásos anyagok az ISO minőségbiztosítási rendszer bevezetéséhez kapcsolódnak. Ezek szerint a minőség,mint munkakultúra feltételezi a humánközpontú vállalkozásvezetési módszereket. Ennek legfontosabb elemei:

- munkatársak elkötelezettsége, a kft. céljainak tudatosítása,

- nagyfokú szakértelem,

- állandó képzés,

- ügyfélközpontúság,.

- a „vállalati kultúra erôsítése”, humán eróforrásmenedzsment,

- az üzleti tevékenység minden mozzanatának pontos dokumentálása,
- a Minőségügyi kézikönyv és a Minőségbiztosítási eljárások kidolgozása és ismerete,

- minőségügyi rendszerstruktúra kidolgozása. (vállalati dokumentumok).

Az 1. vállalatnál a cég alapvetố törekvéseiról a megkérdezetteknek hasonló véleménye van.

A megkérdezettek egyértelmúen az ügyfélközpontúságot tartották a legfontosabb törekvésnek. Teljesen egységes szemlélet tükröződött az interjúkban, ami valószínúleg a személyes kommunikáción, a mindennapos interakciókon alapul. Mint minden szervezetben, itt is mindenki alapvetôen fontosnak tartotta a nyereségességet, a stabil pénzügyi helyzetet, amely minden magánvállalkozás alapvetố célja, azt is megemlítették, hogy fontos, hogy az emberek jól érezzék magukat. Fontos célnak tartotta mindenki a tókeerós nagy cégek megszerzését üzleti partnerként.

A 2. és 3. szervezetben a felsôvezetốk, a stratégia létrehozói természetesen tisztában vannak a vezérlőelvekkel és értékekkel, ók a legfóbb szervezeti értéknek a nagyfokú elkötelezettséget tartották, ami azonban főleg csak rájuk jellemzó.

$\mathrm{Az}$ alkalmazottak többsége nem tudott arról, hogy lenne egy vagy néhány megfogalmazott, hosszú távra szóló vezérelv, illetve stratégia. De mindannyian említették mint alapvető törekvést a szervezetben az ISO minôsítésnek való megfelelésre való törekvést, a szervezet fennmaradását, növekedését, nyereségességét mint saját alapvető érdeküket is, azaz munkahelyük megtartását, ez utóbbit mindenki alapvetô személyes érdekének tartja. Ezenkívül az ügyfeleknek való megfelelést, a terjeszkedést a piacon is fontosnak tartják. A szervezet alapvetô értékei, ami a tagok viselkedését irányítja: a minőségre törekvés, a szervezet növekedése, a piaci részesedés megtartása és növelése, a nyereségesség megôrzése és növelése. Ezekkel az értékekkel, amelyek célokként is megjelennek, úgy túnik, a tagok azonosulnak.

A 4. szervezet legfő́bb célja veszteségeinek csökkentése, majd megszüntetése, további célok a tevékenység mennyiségének és minôségi színvonalának emelése.

„Nincs stratégiája, illetve állandóan születnek stratégiák, de mivel másfél, illetve kétévente vezérigazgató váltás van, ezek el is tünnek, senki nem veszi komolyan.” Azonban sok családból több generáció dolgozik ennél a szervezetnél, ezek a tagok már otthonról hozzák a szervezet fontosabb értékeit. Az alsóbb szinteknek ezek a családból hozott, mégis közös szervezeti értékei: „a fegyelmezettség, pontosság, precizitás, szolgálat (a szó nemes értelmében), az emberi értékek. Alulról jönnek, még megmaradtak. A vezetók is ezt várják el, de annak nincs hatása az emberekre." 


\section{A változásokkal kapcsolatos vélemények,} beállítódások

$\mathrm{Az}$ 1. vállalatnál a változásokat természetesnek tekintik. A szervezeti struktúra és a tagok viszonylag állandóak. A szükséges tudás gyorsan változik, évente több szakmai tanfolyamon vesznek részt, követik az újdonságokat, ezt szeretik a munkájukban, kihívásnak tartják. A cég fizeti és támogatja a képzéseket, az új technológiák minél előbbi megismerését.

A 2. és 3. vállalatnál jelentôs különbség található a vezetés és az alsóbb szintek között. A vezetők látják a változások értelmét, jelentősnek és fontosnak tartják azokat. Az alsóbb szinteken a változásokat az utóbbi két évben soknak találják. Az 2. szervezetben egy évvel ezelőtt történt egy nagy szervezeti átalakulás, divizionális szervezeti struktúrát alakítottak ki, erról azonban gyorsan kiderült, hogy nem megfelelő, a divíziók túlságosan a saját érdekeiket képviselték, komoly integrációs problémák keletkeztek, több embert elbocsátottak. Jelenleg a vezetés megint átalakítja a szervezeti struktúrát, néhányan már látják körvonalazódni a változásokat, több megkérdezett nem tudja, milyen változások lesznek, de félnek tóle. Néhányan úgy látják az embereknek túl sok ennyi változás, rosszul fogadják, félnek a jövőtoól, csökkent a bizalom, kis csoportokban megindultak a találgatások. „Most már lehet sejteni, hogy mi lesz, de kimondani nem lehet."

A vezetés fontosnak tartja, hogy a tagok támogassák a változásokat, önállóak, piacképesek legyenek. A változások kialakításában a vállalat külsô szakértôk segítségét vette igénybe. Néhányan, akiket bevontak a tervezésbe, és úgy látják pozíciójuk javulni fog, figyelembe vették véleményüket, hívei a változásnak, támogatják azokat.

A 3. szervezetben a vállalatot a vezetók a régióban az első helyek egyikére helyezik el, de országos viszonylatban is jelentósnek tartják. A vezetók szerint az utóbbi idốben fontos változások történtek. A vezetók a vállalatot innovatívnak, a környezethez való viszonyát proaktívnak látják (szakmai kiállítások, előadások, találkozók a gyártókkal), nemrég történt egy nagyobb átalakítás a struktúra és a folyamatok szervezése terén, amelynek közvetlen kiváltó oka az alsó szintek nagyfokú elégedetlensége volt. A súlyos túlterheltség nagy felháborodást okozott. A vezetés csapatmunkában kidolgozta az új feltételeket, szerintük az alsó szintek jól fogadták az újításokat. A nem vezetốk nem észlelnek innovációt, kezdeményezést, habár előfordult, hogy egy-egy ötletüket elfogadták. A környezet változásait szerintük a szervezet lassú, követő magatartása jellemzi.

A 4. vállalatnál a változások egyik formája, hogy bizonyos tevékenységeket a szervezet tulajdonában lévő kft-k végeznek, tevékenységüket a „szabad piacon” is értékesíthetik, a náluk képződő hasznot azonban a 4. szervezet elvonja. A másik az ismétlődő elbocsátások sorozata, ami félelemmel tölti el az embereket és az ott maradók egyre túlterheltebbnek érzik magukat.

A különböző szakterületek és igazgatóságok között is erős versengés folyik. A szervezet „valószínúleg sikeresebben múkködne, ha nem volna szakadék a különböző hierarchikus szintek között.” A munka- és felelősségi körök pontosan elhatároltak.

\section{A vezetési stílus}

$\mathrm{Az}$ 1. vállalatnál a vezetési stílust barátinak, közvetlennek tartják. A vezetés az új ötleteket, javaslatokat támogatja, általában meg is valósulnak. A stratégiai döntéseket az öttagú vezetőség hozza, ebből négy fó tulajdonos. Növelte a szabályozottságot és a formalizáltságot az ISO minôsítés, mindenki kézhez kapja a leírt szabályokat, erról jó véleményük van.

A 2. szervezetben a ,régi tagok”, akik 6-8 éve a szervezetben vannak, nagyon autokratikusnak látják a vezetési stílust, az átalakulás megkezdése után munkába lépett tagok (néhány hónapja dolgoznak a szervezetben) demokratikusnak, illetve bevonónak látták. Míg a vezetốk önálló, kreatív, új piacokat szerzô munkatársakat szeretnének, az alsóbb szinteken a legtöbben úgy látják, hogy minden a legfelsố szinten dốl el. Az embereknek lehetnek ötleteik, de ezekkel el kell jutni az ügyvezetôig, és nagyon jól kell tudni érvelni, hogy meggyőzzék, azaz meg kell küzdeni az ötletek megvalósulásáert. Néhányan úgy látják, hogy a szervezetben elindult egy demokratizálódási folyamat, az ügyvezetô delegálta volna pl. a döntést a divízióknak, de erre nem mindegyik volt képes, több vezetô nem is akar dönteni.

A 3. szervezetben a vezetốk a vezetési stílussal elégedettek, korrektnek, gyakran bevonónak találják, a nem vezetốk autokratikusnak találják, és a korrektséget hiányolják. „Megmondják, hogy mit kell csinálni, de ehhez a feltételek nem biztosítottak. Pont annak nem kérik ki a véleményét, aki a témában a legjobban benne van, akinek a munkájáról döntenek." A vezetők említették, hogy az alsóbb szinteken nagy a fluktuáció, de nem tudják, hogy miért.

4. vállalat: „A szervezetre régebben jellemző volt a katonás rend, ennek ellenére dicsőség volt ott dolgozni, ma lassan szégyen lesz bevallani." A vezető-beosztott kapcsolat hierarchikus, utasítások szabályoznak mindent, nincs demokratizálódási folyamat. „A munkaügyi kapcsolatok az útszéli szintre süllyedtek. Egy éve nem beszéltem az igazgatóval. Nem kíváncsi rám, így aztán én sem rá.” „Minden vezetônek meg van kötve a keze. Pontosan megszabják, hogy milyen területen, milyen 
határok között dönthet. A vezérigazgató kiad egy rendelkezést, mely lemegy a legalsó szintekig, s ott végre kell hajtani, attól függetlenül, hogy az ott jónak vagy rossznak bizonyul.... A döntések előtt sem kérdezik meg azokat a szinteket, akikról döntenek, a felsôszinten eldöntik a dolgot, és azt végre kell hajtani, függetlenül attól, hogy mennyire hajtható végre egyáltalán az adott helyen. Néha van lehetôség bizonyos fokú módosításra, erre azonban külön engedélyt kell szerezni, ami igen sok időbe telik." A vezető-beosztott kapcsolatot sokan formálisnak tartják, már az is nagy szó, ha a vezetôk meghallgatják a beosztottat. Az alulról jövő panaszokat eltüntetik a bürokrácia útvesztôiben. A beosztottak úgy védekeznek ez ellen, hogy passzívan viselkednek, összefognak, hogy kikerüljék az ellenőrzést, és hogy jobban végezhessék az általuk fontosnak tartott feladatokat.

\section{Munkahelyi légkör}

Az 1. szervezetben a munkahelyi légkört mindenki jónak tartja, szeretnek itt dolgozni, öt év múlva is itt képzelik el magukat, hajlandóak külön erófeszítéseket tenni a szervezetért. A munkaterhelés változó, néha nagyon nagy, pl. pályázatok idején. Ilyenkor nagy a nyomás, sok dolgot kell egyszerre elvégezni, amikor nincs túl sok feladat, a ledolgozott pluszórákkal csökkenthetô a munkaidő. A csoportos munka jellemző a szervezetben, a feladatokat csapatban tudják ellátni, több szakember kell egy-egy feladat elvégzéséhez.

A 2. szervezetben a munkahelyi légkört a megkérdezettek többsége jónak tartja, habár a régóta itt dolgozók jelentôs változásról számolnak be. A kezdetben családias légkörú vállalat a méret növekedésével egyre formálisabb lett, csökkentek az informális kapcsolatok és összejövetelek. Megnôttt a munkaterhelés, a különmunka vállalása megszokott, megfizetik. A negatív jelenségek az elmúlt két év változásai következtében tovább fokozódtak, néhányan úgy látják, a légkör feszültebb lett, a kommunikáció formálisabb, a bizalom csökkent, „nőtt a félelem a másiktól.” A munkájukat legtöbben szeretik, sokan látnak fejlődési lehetőségeket. Vannak közös és egyéni képzések, nyelvoktatás, a vezetô maga is tanul, támogatja a tanulást. A versengés mértékét normálisnak tartják, habár a divíziók között kiéleződött.

A 3. szervezetben a vezetôk elégedettek, kihívónak találták a munkát és a fejlődési lehetőségeket, az alsóbb szinteken ezek hiányát észlelték. „Ha a vezér bent van, nagyon stresszes a társaság. Távollétében ugyanúgy elvégzi mindenki a feladatát, viszont érezhetôen jobb a légkör." A nagy munkaterheléshez képest alacsonynak tartják a fizetést. Sok a tapasztalatlan fiatal a szervezetben, ók valószínúleg olcsóbb munkaerót jelentenek.
Az alsóbb szinteken úgy látják, hogy gyakoriak a konfliktusok, „állandó az idegeskedés”. Gyakran hazudni kell a vezetônek, mert a problémák miatt nem tudják idóben kiszolgálni a vevốt.

Ebból a szempontból a minôségbiztosítási rendszer szerepe ellentmondásos. A vezetók is észrevették, hogy az alsóbb szintek nem azonosultak az ISO minőségbiztosítási rendszer követelményeivel. Az alsó szinteken az ISO „mint egy csomó pluszmunka” jelenik meg. Csak a vezetốk látják és érzik a hasznát. Rendszeresen vizsgáznak a kézikönyvból, az audit sok adminisztrációt követel. A nem vezetók negatívan fogadták az új feladatokat, többletadminisztrációt, számonkérést, amit független minőségügyi vezető bármikor megtehetne.

Mindenki úgy látja, hogy az ISO bevezetésével nôtt a formalizáltság foka, a munkakörök pontosan elhatárolhatóvá váltak, a rugalmasság csökkent, míg a vezetôk azonban ennek látják értelmét, a beosztottak nem. Így romlott a munkahelyi légkör, habár a felsővezetésben erófeszítéseket tettek ennek javítására. Minden osztály minden hónapban a vállalat költségén elmehet együtt vacsorázni, kötetlen formában találkozni. Errôl jó a vélemény, de a problémákat nem oldja meg.

A 4. szervezetnél gyakori a létszámleépítés. A rendszerváltás óta a munkaerô-állomány a felére csökkent. Egy átvilágítás után további elbocsátásokat javasoltak. Ennek ellenére többen úgy vélik, hogy sok helyen létszámhiánnyal folyik a munka, és az ott dolgozók túlterheltek, ebból súlyos balesetek is származtak. Gyakori, hogy egy ember három munkáját végzi egy fizetésért. Ez az egyik oka a rossz munkahelyi légkörnek. Többen úgy látják, hogy ,a vezetók szinte várják, hogy a munkavállaló hibázzon, és szankciót lehessen vele szemben alkalmazni”. A problémák megoldásáert ritkán tesznek valamit. Sokan úgy vélik, hogy a munka feltételei rosszak, a berendezések elavultak. A szervezetben a munkavégzés feltétele különböző képzések elvégzése, az oktatás felszínes és gyenge színvonalú. A megkérdezettek rendkívül „stresszesnek " és rossz légkörúnek tartják a vizsgákat. Oktatni, tanulni kellene, de nem így. Mindenféle külsô képzés teljesen érdektelen a vezetés számára. Ennek ellenére létezik bizonyos fokú lojalitás. Ez egyrészt a munkahely elvesztéséból származó félelemból táplálkozik, másrészt a tradíciókból, a megórzött értékekből.

Nemrég megszüntették a bértarifarendszert, és a teljesítménytôl függó differenciálást vezették be, nincsenek azonban értékelési kritériumok. „Ezzel végképp sikerült a vezetôket leválasztani az alsóbb szintekról, egyszerúen megvásárolták ôket. A különböző szintú vezetớk látszatfeladatokért kapnak pénzt, egyszerú bábfigurák. Ezzel persze mindenki tisztában van.” 


\section{A kommunikáció}

Az 1. szervezetben a kommunikációról megoszlanak a vélemények. Míg az elsố megkérdezett nagyon jónak tartja, a második csak közepesnek. A hírek, a fontos információk nem terjednek elég gyorsan, ennek oka az, hogy a tagok nagyon elfoglaltak. Nagymértékú az informalitás a kommunikációban, nem számítanak a hivatalos utak. A munka- és felelósségi körök nem elhatároltak, ez jelentôs tényezôje a rugalmas és gyors reagálásnak. Mélyebb konfliktusok nincsenek, inkább csak ritkán fordulnak elő súrlódások, ezt természetesnek tartják.

A 2. szervezetben az új tagok úgy látják, hogy az ellentétes nézetek nyíltan vállalhatók, a régiek szerint a konfliktusokat el kell kerülni, és a küzdelmek a háttérben zajlanak. „A kommunikáció nem lehet tökéletes, jelentős torzulások mennek végbe, próbáljuk tökéletesíteni, inkább írásossá tenni, új hírlevelet tervezünk, amelyben szerepelni fognak a fóbb vállalati célok, elvárások." A vállalat tervezett újításai, amelyekról csak néhány vezetố tudott, kiszivárogtak, a kisebb rugalmasabb cégek, amelyek erról értesültek, így előnyhöz jutottak. Ez az esemény a szervezet utóbbi két évben lezajlott válságos idôszakának része, amely hozzájárult a bizalom a megkérdezettek által említett csökkenéséhez. Az információk áramlását sokan problémának látják, gyakori az információk visszatartása, hiánya.

A 3. szervezetben a horizontális kommunikáció jobban múködik, mint a vertikális. A beosztottak úgy látják, hogy a felsővezetés nem foglalkozik problémáikkal. Néhány hónappal ezelőtt az érdekellentétek a felszínre kerültek, heves viták, nézeteltérések voltak, ennek következménye lett az említett szervezeti átalakítás. A vezetốk ezt problémamegoldásnak észlelték, a beosztottak olyan megoldásnak, ahol pont az érintettek véleményét nem kérték ki.

A 4. vállalatnál mindezek ellenére néhányan úgy látják, hogy a kommunikáció terén javulás tapasztalható. Egyesek szerint a PR a 4. szervezet legsikeresebb üzletága, egy „profi kommunikátor” irányításával. Ez kifelé és befelé hasonló stílusban történik, csak belül a dolgozók a szervezet újabban megjelenő újságját csak azért veszik a kezükbe, hogy „röhögjenek rajta”. Hiányzik a bizalom. A konfliktusokat teljes mértékben elfojtják.

\section{Összegzés}

Kultúravizsgálatunkat a szervezeti tagok észleléseire alapoztuk. A vizsgált témakörök mindegyike tulajdonképpen ugyanazon dolog, a szervezeten belüli emberi kapcsolatok és viselkedések jelenségvilágának különbözô oldalait fejezik ki.
A szervezetek vezetôire nagymértékú, a versenyból fakadó nyomás nehezedik, hogy nagyobb hatékonyságot érjenek el, arra azonban nincs egyértelmú válasz, hogy az általuk vezetetteket hogyan tudják rábírni erre. A menedzserek nyilván kíváncsiak, hogy mitól hatékonyabb az egyik vállalat a másiknál. A vállalati kultúrát napjainkban sokan tartják sikeres vállalati múködés sarkkövének, a szervezetek gyakorlatában azonban nehezen érhetố tetten a kultúra közvetlen üzleti relevanciája.

A szervezetek gyakorlatának ismert jelensége a hierarchia különböző szintjein lévô csoportok különbözô szubkultúrává válása, ennek következtében a helyi gyakorlat és a „fentról jövő hivatalos gyakorlat” eltéréseinek kialakulása. A kérdés, hogy mekkora ez az eltérés, $s$ hogy nem lépi-e át azt a mértéket, amely inkább akadályozza, mint elősegíti a szervezet hatékony múködését. Kutatásaink arra hívják fel a figyelmet, hogy az említett csoportok könnyen válnak ellenséges szubkultúrává, és az alárendeltek sokféle rejtett módon képesek érdekeiket érvényesíteni, és saját elképzeléseiket megvalósítani, akár a szervezeti célok ellenében is. Ennek elkerülése érdekében feltétlenül fontos olyan kommunikációs csatornák kiépítése, amelyeken a különböző csoportok eltérő logikái és értelmezései találkozhatnak, ütközhetnek, és a legfontosabb területeken konszenzusra juthatnak.

A vizsgált vállalatoknál az emberi kapcsolatok terén a kicsitól a nagy felé haladva, egyre több negatív véleményt hallottunk. A kis szervezetben a természetesen kialakuló organikus szerveződések megnyilvánulnak a tagok elégedettségében és a jónak észlelt szervezeti légkörben. A középvállalatokban a növekedéssel szükségszerúen bekövetkező bürokratizálódást és a szervezeti kultúra mechanikus vonásainak erôsödését a hierarchia alsóbb szintjein a vezetéstól való elszigetelődésként és helyzetük romlásaként élik meg.

Az integrációs irányzat szerint a vezetók szerepe meghatározó a kultúra alakulásában (a vezetố mire figyel, és mire nem, mit mér, és mit ellenóriz, szerepmodellként milyen viselkedést tanít, milyen elvek szerint osztja el az eróforrásokat és jutalmakat stb.), s léteznek közösen osztott értékek. Hasonlóan fontosnak túnnek azonban a szubkultúrák és az egyéni észlelések, amelyek bizonyos dimenziók mentén óriási különbségeket mutattak. A vizsgált szervezetekben az egyik kritikus tényezônek az információk áramlása, a kommunikáció hatékonysága tünt, minden szervezetben e tényezóvel voltak a legelégedetlenebbek a megkérdezettek. A kultúra befolyásolása szempontjából tehát a kommunikáció az egyik legfontosabb dolog, amit a vezetóknek jól kellene csinálniuk. A szervezeti méretek növeke- 
désével az eltúnóben lévő személyes kommunikáció hiánya egyre súlyosabb problémákat okoz. A Peters - Waterman szerzópáros által „körbesétálós” vezetésnek nevezett vezetési stílus úgy látszik napjainkig nem veszített értékéból.

Minden szervezetben megjelenik a minőségbiztosítási rendszerek valamely formája mint kultúrát formáló tényezô. A szervezeti méretek növekedésével azonban e rendszerek gyakorlati megvalósulásának ellentmondásai is egyre szembetûnóbbek. A minôség mint munkakultúra a vállalati kultúrák organikus jellegének növekedését kívánná meg, e törekvés meg is jelenik a deklarált célokban. A megkérdezettek többsége azonban e folyamatokban fóként a mechanikus szerveződések fokozódását észlelte, amelyek számukra értelmetlen és fárasztó adminisztratív tehernövekedés formájában jelentek meg, ami fokozta a munkahelyi elégedetlenséget és a túlterheltséget.

A tudást és tanulást minden szervezetben a központi értékek közé sorolták, azonban e mögött egészen különböző értelmezéseket találtunk. A szervezetek többségében az explicit tudásfajtákat részesítik előnyben, ezek jól megférnek a mechanikus kultúrával, míg az organikus kultúrában az implicit tudásfajtákon van a hangsúly. A menedzsment-szakirodalom tanulmányok ezreit szenteli az implicit tudás és tanulás jelentőségének taglalására, e tudásfajták menedzselési módszereinek és kulturális feltételeinek kidolgozására, a vállalati gyakorlat azonban úgy túnik, megelégszik az explicit tudásfajták mechanikus növelésével, tárolásával és számonkérésével.

A nemzetközi összehasonlítások egy része a hazai vállalatok körében a hatalmi kultúra magas szintjét mutatta ki, ezt részben a múlt örökségének tekintik. Ennek jellemzői, az autokratikus vezetésfelfogás és a hatáskörök nagyfokú centralizáltsága, és az egyenlőtlenségek nagyobb elfogadottsága (Bakacsi, 1998). A szervezeti méretek növekedésével a megkérdezettek egyre autokratikusabb vezetésfelfogást észlelnek, ennek legdurvább megnyilvánulási formáit a 4. szervezet tagjai írták le. Mondhatnánk, hogy ez egy tipikus szocialista nagyvállalat fennmaradt kultúrája, a megnövekedett egyenlőtlenségeket, és az ezek következtében kiéleződött konfliktusokat a tagok azonban nem fogadják el, inkább nagyon is kritikusan szemlélik.

Az eredményekből egyértelmúen kiderül a vállalati kultúra jelentósége a minőségre törekvés, a fogyasztóorientáltság, az elkötelezettség, az együttmúködés, a kommunikáció és a szervezeti célok tudatossága terén. $\mathrm{E}$ tényezók a szervezetek múködésének alapvető fontosságú elemei. A fent leírtak alapján a vezetés szempontjából a kultúra témakör egyik legfontosabb mondanivalója, hogy felhívja a figyelmet arra, hogy a hierarchia alsóbb szintjein lévók értékei, attitúdjei, véleményei is döntő tényezối a munkahelyi elégedettségnek, a jó szervezeti kommunikációnak, az együttmúködésnek és a tudás megosztásának. Mindebból arra a következtetésre juthatunk, hogy ennek megismerése személyes kommunikáció útján, valamint figyelembe vétele a döntésekben a vezetés lényeges eleme, amenynyiben a menedzsment szeretné, ha vállalata birtokolná azt az energiát, ami „hajtja a szervezetet” (Schein, 1991).

\section{Felhasznált irodalom}

Asanullah, A. -Asp, E. (1995): A vállalati kultúra mint sikertényezô. Vezetéstudomány, 12. szám

Bakacsi, Gy. (1998): Szervezeti kultúra és leadership nemzetközi összehasonlításban. BKE Jubileumi tudományos ülésszak. 1998. okt. 1-3. Harmadik kötet, 2162-2171. o.

Bakacsi, Gy. - Sarkadi - Nagy, A. (2003): Latinos magyar leadership - vezetésfelfogásunk a GLOBE kutatás tükrében. Alkalmazott Pszichológia, 3-4. szám

Bakacsi, Gy. - Takács, S. (1998): Honnan - hová? A nemzeti és szervezeti kultúra változásai a kilencvenes évek közepének Magyarországán. Vezetéstudomány XXIX. évf. 2. szám, 15-22. o.

Barakonyi, K. (1996): A vállalati kultúra megváltoztatása. Ipargazdasági Szemle, 1-3. sz. 157-168. o.

Bittner, P. (1999): Tanuló szervezetek Magyarországon? Gazdaság-Vállalkozás-Vezetés, 2. szám

Borgulya, I - Barakonyi, K. (2004): Vállalati kultúra. Nemzeti Tankönyvkiadó, Budapest

Bowman, C. - Ambrosini, V. (2000): Value creation Versus Capture: Towards a Coherent Definition of Value Strategye. British Journal of Management, Vol. 11, pp. 1-15.

Bógel, Gy. - Salamonné, Huszty A. (1998): Vállalatvezetés felsőfokon. Kossuth K. Bp.

Bryman, A (1991): Society as a model for research into organizational culture. In: P. J. Frost - L.F. Moore-M.R. Louis - C.C. Lundberg - J. Martin (eds), Reframing Organizational Culture.

Burns, T. - Stalker, G. M. (1961): The Management of Innovation. London, Tavistock.

Child, J. (1984): Organisations: A Guide to Problems and Practice. Harper \& Row, London

Cooke, R..A, - Rousseau, D. M. (1988): Behavioural norms and expections: A quantitative approach to the assessment of organisational culture. Group and Organisation Studies, 13. pp. 245-273.

Deal, T. - Kennedy, A. (1982): Corporate Cultures: The Rites and Rituals of Corporate Life. Rading, MA., AddisonWesley

Denison, D.R. (1990): Corporate culture and organisational effectiveness. New York, John Wiley 
Drótos, Gy. - Nemeslaki, A.: A hálózatok szervezôdési modelljei. Az e-business üzleti modelljei. Előadás. BCE, 2005. március 30 .

Ebers, M. (1985): Organisationskultur: ein neues forschungsprogram? Gabler GmbH, Wiesbaden

Farkasné, Déri K. (1990): A vállalati kultúrák helye a paradigmák változásában. Ipar-Gazdaság, 10. szám, pp. 24-29.

Heidrich, B. (2001): Szervezeti kultúra és interkulturális menedzsment, Human Telex, Budapest

Hofstede, G. (1991): Cultures and Organisations: Software of the Mind. London: McGraw-Hill

Jermier, J.M.M (1991): Critical epistemology and the study of organizational culture: Reflections on Street Corner Society. In: P. J. Frost - L.F. Moore - M.R. Louis - C.C. Lundberg - J. Martin (eds), Reframing Organizational Culture

Kapás, J. (1999): A vállalat tudása. Vezetéstudomány

Keszeg, J. (1999): A dolgozók munkakialakítási kompetenciájának szerepe és jelentôsége a vállalatok életében. OMIKK - Korszerú vezetés, 11. 17-27. o.

Kocsis, É. - Szabó, K. (2000): A posztmodern vállalat (Oktatási Minisztérium)

Koenne, B.A. - Boone, C.A. - Soeters, J.L. (1997): Organisational Factors Influencing Homogenity and Heterogenity of Organisational Cultures. In: S.A. Sackmann (ed) Cultural Complexity in Organisations. pp. 273-293., SAGE Publications

Mastenbroek, W.F.G. (1991): Konfliktusmenedzsment és szervezetfejlesztés. KJK., Budapest

Málovics, É. - Behrends, T. (2002): A szervezeti kultúra fogalma a menedzsmentelméletekben. A komplexitás nyomában. Marketing\&Management

Meyerson, D.E. (1991): A glimpse of an occupational Culture. In: P. J. Frost - L.F. Moore - M.R. Louis - C.C. Lundberg - J. Martin (eds), Reframing Organizational Culture

Meyerson, D.E. (1991): Acknowledging and uncovering ambiguities in cultures. In: Reframing Organizational Culture (edited by: Peter J. Frost, Larry F. Moore, Meryl Reis Louis, Craig C. Lundberg, Joanne Martin)

Miller, G.J. (2002): Menedzser-dilemmák. Aula Kiadó, Bp. Ouchi, W.G. (1979): Markets, Bureocracies and Clans. Administrative Science quarterly. Vol. 25. March

Peters, T.J. - Waterman, R. H. (1986): A siker nyomában. Kossuth Könyvkiadó, Budapest
House, R.J. - Wright N.S. - Aditya, R.N. (1997): New Perspectivess on International/Organisational Psychology. The New Lexington Press, San Francisco

House, R.J. - Hanges, P.J. - Ruiz-Quintanilla, S.A. Dorfman, P. W. - Javidan, M. - Dickson, M. (1998): Cultural Influences on Leadership and Organisations: Project GLOBE. JAIPress

Rollett, Brigitte - Bittner, Ulrike (2000): Effort Avoidance at the Work Place. Fairness \& Cooperation, IAREP/ SABE 2000, Vienna/Austria,Conference Proceedings. Universitätsverlag, Wien

Rousseau, D.M. (1990): Assessing organisational culture: The case for multiple methods. In: Schneider, B. (ed.), Organisational Climate and Culture. San Francisco: Jossey-Bass

Sackman, S.A. - Phillips, M.E. - Kleinberg M.J. Boyacigiller, N.A. (1997): Single and multiple cultures in intrnational cross-cultural management research: Overview. In: Sackmann, S.A. (ed): Cultural Complexity in Organizations

Schein, Edgar, H. (1985): Organisational Culture and Leadership. Jossey-Bass Publishers, San Francisco - Washington - London

Schein, E.H. (1990): Organisational culture. American Psychologist, 45. pp. 109-119.

Schein, E.H. (1991): The role of the founder in the creation of organizatinal Culture. In: Reframing Organizational Culture (edited by: Peter J. Frost, Larry F. Moore, Meryl Reis Louis, Craig C. Lundberg, Joanne Martin)

Schein, E.H. (1991): What is culture? In: Frost, P.J. - Moore, L.F. - Louis, M.R. - Lundberg, C.C. - Joanne Martin, J. (eds), Reframing Organizational Culture

Schneider, B. - Reichers, A.E. (1983): On the Etiology of Climates. Personell Psychology, 36. pp. 19-39.

Sigmund, F. (1992): Rossz közérzet a kultúrában. Kossuth K., Budapest

Smircich, L. (1983): Studying Organisations as Cultures. In: Morgan, G (ed.) Beyond Method: Strategies for Social Research. Sage, London

Varga, K. (1982): Szervezeti kultúránk koordinátái. Ergonómia, 3. sz. 130-143. o.

Wilmott, H. (1993): Strenght is Ignorance, Slavery is freedom: Managing Culture in Modern Organisations. Journal of Management Studies, 30(4), pp. 515-551. 